\title{
DIALOGISUUDEN YMMÄRTÄMINEN KONSULTOINNISSA
}

\author{
Näkökulmana tutkiva konsultointi, relational consulting
}

\begin{abstract}
Tutkivassa konsultoinnissa dialogi-käsitteellä kuvataan ennen kaikkea viestinnän ja yhteistyön luonnetta. Siihen liittyy käsitys, että ihmisten välisellä vuorovaikutuksen laadulla on suuri merkitys muutoksissa, joita tapahtuu yhteistoiminnan tuloksena. Dialogissa on kyse toisen ihmisen kohtaamisessa syntyvästä kokemuksesta, joka muuttaa jollain tavoin ihmistä itseä. Lähtökohtana on psykodynaaminen ajattelu: ihmisen mielen sisältö on syntynyt suhteessaolon kautta.
\end{abstract}

\section{EIJA VARTIAINEN}

$\mathrm{D}$ ialogi, yhteistoiminta, valtaistaminen, tunneälyn kehittäminen, hiljainen tieto ja oppiva organisaatio ovat käsitteitä, jotka ilmestyivät 1990-luvulla työelämän kehittämiseen. Mekanistisen, kausaaliselityksiin pohjaavan tieto- ja maailmakäsityksen rinnalle nousi emansipatorinen, intentionaalisiin perusteisiin nojautuva tieto-ja maailmakäsitys, jota mm. Heikki Mäki Kulmala (2004) on tässä lehdessä mielenkiintoisella tavalla valottanut.

Siirtyminen fordistisesta massatuotannosta asiakas-ohjautuvaan ja räätälöityyn massatuotantoon sekä tiimityöskentelyyn loi konsultoinnille uudenlaisen tarpeen ja markkinat. Konsultointi onkin 1990-luvulta kasvanut merkittäväksi ammatiksi ja työelämän kehittämisen sekä aikuiskasvatuksen muodoksi. Konsultointi tapahtuu aina ihmisten välillä ja vuoropuhelussa. Tässä artikkelissa tarkastelen konsultointia dialogisuuden näkökulmasta. Määrittelen ensin dialogin ja konsultoinnin käsitteet. Sen jälkeen tarkastelen dialogia konsultointiprosessissa sekä konsultoinnin metodien valinnassa. Artikkelin viitekehys on tutkiva konsultointi - relational consulting. Sen lähtökohdat ovat tavistockilaisessa konsultointi- ja kehittämistraditiossa (ks. Miller 1996).

\section{MITÄ ON DIALOGISUUS}

Dialogi on inhimillisen kanssakäymisen olennai- nen osa ja elämän perusmuoto (Damasio 1994). Neurobiologisesti ihmisen keho rakentuu dialogisesta suhteesta. Holistisen ihmiskäsityksen mukaan ihmisen tajunnallinen olemassaolon tapa on perusluonteeltaan dialogi todellisuuden kanssa (ks. Rauhala 1983, 1989). Dialogilla kuvataan yhteistyötä ja keskinäistä viestintää, joka on mahdollista niin sisäisenä puheena minän ja alter egon

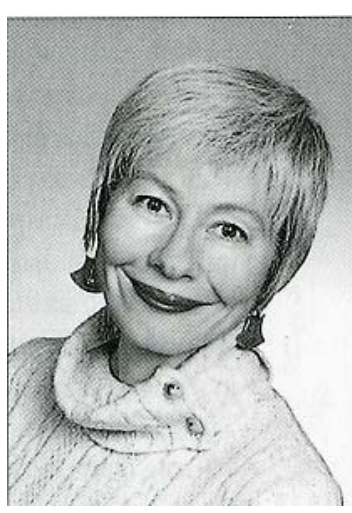

Eija Vartiainen välillä sekä minän ja lukuisten toisten välillä. Dialogi on siis vastavuoroista, tajunnallista kanssakäymistä ja ajattelua sekä sisäistä puhetta (Lehtovaara 1996: 213, Varto 1996: 83). Dialogin juuret löytyvät antiikin Kreikasta ja Sokrateelta.

Käsite 'dialogi' viittaa kantasanaansa dialogos, joka tarkoitaa välissä olevaa ja läpi virtaavaa (ks. Bohm 1996,6). Fenomenologit kuten Martin Heidegger, Hannah Arendt, Martin Buber ja Emmanuel Levinas ovat päätyneet käsitykseen, että ihminen ei luonnostaan tiedä paikkaansa maailmassa. Hän on mysteeri myös itselleen. Saadakseen selville paikkansa maailmassa ja suhteessa toiseen, on ihmisen täytettävä hänen ja 
tuon maailman ja toisen henkilön väliin jäävä avoin tila ${ }^{1}$ jollakin, joka mahdollistaa yhteyden. Tuo väliin jäävä avoin tila (open space) on ymmärrettävissä potentiaaliseksi tilaksi. Se on luova tila, yhdistymisen eli integraation paikka. Myös psykoanalyytikko Donald Winnicot (1971) on päätynyt saman suuntaiseen käsitykseen. Suhde, dialogi ja avoin tila liittyvät toisiinsa.

Dialogi on vastavuoroista vaikuttamista. Se ei ole monologia, jossa toinen on kohde, jota informoidaan. Dialogia ei tule myöskään ymmärtää interaktioksi, joka noudattaa ärsyke-reaktio mallia, vaan se on persoonien välistä interpersoonallista tapahtumista. Dialogilla on transformatiivinen luonne, jonka mukaisesti se synnyttää aikaisempaa syvempää ymmärrystä sekä uusia yhteyksiä Tämä erityispiirre erottaa dialogin tavallisesta keskustelusta.

Tutkivassa konsultoinnissa dialogi-käsitteellä kuvataan ennen kaikkea viestinnän ja yhteistyön luonnetta. Siihen liittyy käsitys, että ihmisten välisellä vuorovaikutuksen laadulla on suuri merkitys muutoksissa, joita tapahtuu yhteistoiminnan tuloksena. Dialogissa on kyse toisen ihmisen kohtaamisessa syntyvästä kokemuksesta, joka muuttaa jollain tavoin ihmistä itseä. Lähtökohtana on psykodynaaminen ajattelu: ihmisen mielen sisältö on syntynyt suhteessaolon kautta. Se uudistuu ja kehittyy aidossa kohtaamisessa. (vrt. Bion 1967, Puro \& Matikainen 2000)

Käytän siis sanaa 'dialogi' fenomenologisen ja psykodynaamisen merkityksenannon mukaan. Tutkivan konsultoinnin viitekehyksessä se tarkoittaa joka suuntaan etenevää avoimuutta ja vuorokuuntelua niin sisäisen puheen tasolla kuin suhteessa Toiseen. On tärkeää, että dialogi ei jää vain ajattelun ja kielen tasolle, vaan tavoittaa osapuolten kokonaisvaltaisen kokemuksen ja sisäisen puheen (ks. Vartiainen 2003).

\section{MISTÄ DIALOGINEN}

\section{SUHTEESSAOLO RAKENTUU}

Tutkivassa konsultoinnissa dialogisuuden ymmärretään rakentuvan (1) assosiatiivisestä vuoropuhelusta ja (2) assosiatiivisestä vuorokuuntelusta sekä (3) ymmärtämisyhteydestä. Se tarkoittaa, että henkilö on samanaikaisesti suhteessa itsessään olevaan havainnoivaan ja tutkivaan puoleen ns. tutkija-tarkkailijaan sekä kokevaan puoleen eli toimijaan.

Ymmärtäminen on dialogisen filosofian mukaan raja-arvo, jota lähestytään. Sen ehtoihin ei voida vaikuttaa ymmärtämistilanteen "ulkopuolelta". Siksi ymmärtäminen on mahdollista vain dialogissa tietyn situaation, kokonaistilanteen puitteissa (Hankamäki 2003, Gadamer 2004). Näin ollen kenenkään ulkopuolisen, konsultin, osallistavan kehittäjän, työelämän tutkijan - mitä nimeä haluamme käyttääkin, näkemä objektiivinen totuus ei voi olla yksilön käytössä ennen kuin se tulee subjektiivisena totuutena koetuksi. Kokevan tajunnan syntyminen ja olemassaolo on ihmiselle sekä hänen omakohtainen olemassaolokokemuksensa että maailman koetun olemassaolon eksistentiaalinen perusedellytys (Tähkä 1997). Jokainen on oman maailmansa ja oman situaationsa keskipiste ja tarkastelee elämää ja asioita siitä käsin. Emme voi vaihtaa keskenämme paikkoja, mutta voimme oppia ymmärtämään miltä asiat toisen paikasta käsin näyttävät.

Reflektio liittyy dialogiseen prosessiin. Sen avulla etsitään ymmärtämisyhteyksiä. Tämä tapahtuu kulkemalla edestakaisin kokonaisuudesta osiin ja osista kokonaisuuksiin. Ymmärtämisyhteyksien etsiminen on sen huomioimista ja pohtimista missä määrin voimme kuvata asioita, ilmiöitä, tekoja, tunteita ja toimintaa niin, että emme huomaamattamme konstruoi niitä totutulla tavalla. (ks. Gadamer 2004)

Tulkinta on dialogisen prosessin viimeisin vaihe. Tulkinnassa ihmisen ennakko-oletukset tulevat testatuiksi. Niitä kokeillaan ja arvioidaan, muutetaan ja vaihdetaan. Merkityssuhteiden tutkiminen ja tulkinta on paitsi omien kunkin hetkisten valintojen, päätösten ja tuntemusten tunnistamista, myös omien kokemusten ymmärtämistä oman elämänhistorian ja -tilanteen valossa. Tulkinta on hermeneuttinen metodi, joka luo mahdollisuuden rakentaa silta ulkoisen ja sisäisen sekä tietoisen että vielä tiedostamattoman välille. Ymmärrän tiedostamattoman bionilaisittain, en freudilaisittain. Bionille (1967) tiedostamaton on jotakin, joka on hämärän peitossa, vastakohtana kirkkaalle ja selkeälle. Kuten yö ja päivä ne liittyvät toisiinsa eikä niistä voi puhua toisistaan irrallaan.

Dialogisen filosofian mukaan tulkinta on suhde, jossa merkitys ilmenee. Tietäminen ei ole mahdollista ilman tulkintoja, jotka ovat arvo- ja subjektisidonnaisia. Tulkitseminen on osa kaikkea tiedonhankintaa. Se muuntaa alkuperäistä ajatusta tulkitsijan oman tajunnan osana (ks. Hankamäki 2003). Dialogisessa prosessissa olennaista on, 
että koko ajan ymmärrys kasvaa kysymysten ja arvausten myötävaikutuksella. Aito dialogi ei koskaan irtoa abstraktiksi keskusteluksi, vaan säilyttää yhteyden perustaansa (Vartiainen 2003).

\section{MITÄ ON KONSULTOINTI TUTKIVAN KONSULTOINNIN NÄKÖKULMASTA}



onsultointi määritellään sanakirjassa neuvon kysymiseksi. Käsitteenä konsultoini voi tapahi pităa sisälläăn suhteen. Konsultointia ei voi tapahtua muualla kuin ihmisten välillä. Koneita ei voi konsultoida, niitä voi ohjelmoida, korjata ja jne. Konsultointi on ihmisten välistä yhteistoimintaa, joka perustuu sopimiseen. Kieli on sopimisen väline.

Tunnettu filosofi Ludvig Wittgenstein puhuu kielipeleistä. Niillä hän havainnollistaa miten samalla sanalla eri yhteyksissä ja eri ihmisten käyttämänä on hyvin erilaisia merkityksiä (ks. Wittgenstein 1999). Jos sopijapuolet eivät puhu yhteistä kieltä eivät he silloin tunnista mitä he sopivat. Yhdessä tekeminen ei ole mahdollista ilman yhteisymmärrystä, joka siis edellyttää sitä, että molemmat osapuolet ymmärtävät toistensa näkökulmia eli ovat dialogisessa suhteessa.

Konsultin ihmiskäsitys määrittelee sen, miten hän asettuu konsultointisuhteeseen ja miten hän ymmärtää oman roolinsa ja toimintansa. Pitääkö konsultti itseään eksperttinä vai onko hän pelastaja tai korjaaja vai mitä? Edustan tutkivaa konsultointia ja tavistockilaista AOC-traditiota. Siinä konsultointi ymmärretään tasavertaisten, mutta erilaisten toimijoiden yhteistyöksi. Konsultti tuo oman osaamisensa yhteistoimintaan sovitun tehtävän puitteissa.

Neuvon pyytäminen tuo konsultointisuhteeseen epätasapainoa. Suhde rakentuu toisesta, jolla on jotakin jota toinen osapuoli tarvitsee ja haluaa. Konsultointi on vaikuttamista ja siihen liittyy vallankäyttöä. Siksi konsultointia tulisi ohjata tietoiset arvot ja tavoitteet sekä eettiset periaatteet. Keskeisin eettinen periaate, arvo ja tavoite on tukea ja kunnioittaa asiakkaan autonomiaa. Eric Miller nosti ne esille vuonna 1967 Kenneth Ricen kanssa kirjoittamassaan teoksessa ja myöhemmin johtamassaan konsultointikoulutuksessa Advanced Organisational Consultancy (ks. Miller 1993, 271). Miller ja Rice kuuluvat tavistockilaisen konsultointi- ja kehittämistyön uranuurtajiin (ks. Vartiainen \& Pulkkis 2004).
Yhteistoiminnallinen konsultointisuhde syntyy molemminpuolisen tarvitsevuuden tunnustamisesta ja sen pohjalta tapahtuvasta yhteistyöstä. Molemminpuolisen tarvitsevuuden myöntäminen mahdollistaa vastavuoroisen, molempia osapuolia palvelevan yhteistoiminnan. Kysymys on realiteettien tunnustamisesta, joista yksi on taloudellinen hyöty.

Tutkivassa konsultoinnissa korostetaan, että konsultointiprosessiin liittyvän toiminnan tulee perustua yhteisen sopimiseen. Sopimisen lisäksi työskentelyn tulee olla kaikkien osallistuvien osapuolten tietoisen arvioinnin alaista. Silloin vaikuttaminen, auttaminen, jos niin halutaan sanoa, ei ole manipulointia. ${ }^{2}$ Asiakkaan oman kehittämiskyvyn kehittäminen on toinen tutkivan konsultoinnin perustavoitteista.

Konsultti kutsutaan organisaatioon useimmiten silloin kun etsitään muutosta ja halutaan kehittyä. Taustalla voi olla kriisi, jossa asiakkaan tai asiakasorganisaation omat voimavarat syystä jos toisesta eivät ole riittäneet. Konsultti on tietyssä mielessä organisaatioiden auttaja. Konsultin tehtävä on aina viimekädessä tehdä itsensä tarpeettomaksi. Mikä tapahtuu, kun asiakas saa voimavaransa uudelleen käyttöön ja oppii kehittämään toimintaansa.

Konsultointiprosessi on aina projekti, jolla on alku ja loppu. Itsensä tarpeettomaksi tekeminen, niin paradoksaaliselta kuin se saattaakin kuulostaa, ei ole ristiriidassa konsultin ammatinharjoittamisen kanssa. Vain loppu voi olla uuden alku.

\section{KONSULTOINTIPROSESSI}

Konsultointiprosessi ${ }^{3}$ alkaa ensimmäisestä yhteydenotosta, joka on joko suullinen tai kirjallinen kontakti. Siitä alkaa myös yhteistoiminnan mahdollisuuksien luominen ja etsiminen. Konsultointisopimusta solmittaessa kummankin osapuolen vastuulla on kartoittaa riittävän hyvin yhteistoiminnan mahdollisuudet konsultointitehtävän suhteen. Muodollinen sopimuksen tekeminen on yhteisen työskentelyprosessin virallinen alku, mutta sen luonne ja sisältö määrittelee koko konsultointiprosessin puitteet. Sen miten yhteistä matkaa tehdään. Ihmis- ja organisaatiokäsitys, arvomaailma ja se, millaista tietoa on totuttu käyttämään toiminnan ja päätösten teon perusteena, ovat ulottuvuuksia, josta yksimielisyyteen pääsy tarjoaa kunnolliset mahdollisuudet arvioida yhteistoiminnan ja yhteisen konsultointiproses- 
sin mahdollisuuksia. Tämä onnistuu parhaiten dialogisessa suhteessa.

Konsultointiprosessin todellinen perusta on psykologinen yhteistoimintasopimus. Tarkoitan sillä sitä, että pelkkä rationaalinen, tiedon tasolla tapahtuva sopiminen ei vielä riitä, koska yhteistyö ei onnistu ilman luottamusta. Luottamus perustuu keskinäiseen kunnioitukseen ja arvostukseen, mikä taas edellyttää rajojen ja erilaisuuden tunnistamista ja kunnioittamista. Näiden asioiden edellytyksenä taas on aito dialogi.

Psykologisessa sopimuksessa vahvistetaan ja viimeistään nyt määritellään toiminnan konteksti eli missä konsultointia tehdään ja mitkä ovat osapuolten positiot, siis kuka tekee milloinkin mitäkin. Siinä vahvistetaan toimintaa ohjaavat arvot ja eettiset periaatteet, kuten miksi tehdään, mitä tehdään ja miten tehdään, sekä se tapa, miten yhteistyötä ja tuloksia arvioidaan. Ilman arviointia oppiminen jää puolitiehen. Psykologinen yhteistoimintasopimus on erityisen merkityksellinen, koska se tehdään useimmiten vähintään kolmen toimijan kesken: konsultin, organisaation johdon edustajan sekä varsinaisen konsultointiasiakkaan kanssa. Mitä laajemmasta konsultointiprosessista on kysymys, sitä tärkeämpää on, että myös luottamushenkilöt otetaan mukaan psykologiseen yhteistoimintasopimukseen.

Psykologinen yhteistoimintasopimus on heuristinen käsite. Sen sisältö tulee tarkistaa ja vahvistaa toistuvasti konsultointiprosessin kuluessa. Konsultti ei voi milloinkaan tietää, millaiseen sisäiseen viitekehykseen hänen antamansa tieto sijoittuu asiakkaan ja sidosryhmien mielessä. Erilaiset tiedostamattomat uskomukset ja olettamukset voivat muodostua yhteistoiminnan esteiksi. Niiden välttämiseksi ja konsultin omien ymmärtämisvaikeuksien voittamiseksi hänen tulisi tarkistaa ja aina tarvittaessa uudelleen selventää viestintää ja peruskäsitteitä eli ylläpitää aitoa dialogia.

\section{DIALOGINEN TYÖSKENTELY- TAPA JA METODIT}

Dialogi edustaa siis tietynlaista tapaa olla suhteessa, toimia ja työskennellä yhdessä. Konsultointiprosessissa voidaan tehdä erilaisia interventioita ja soveltaa erilaisia metodeja. Tyypillisiä interventioita ovat erilaiset koulutuspäivät. Koulutus edustaa perinteisesti monologista suhteessaoloa. Siinä toinen joka osaa kertoo, opettaa toi- selle joka ei osaa. Koulutuksiin on pyritty ottamaan mukaan vastavuoroisuutta mm. palautteen annon ja erilaisten kommenttien muodossa. Kommentit eivät kanna dialogiin saakka vaan jäävät irrallisiksi monologeiksi.

Uudempaa toimintatapaa edustavat erilaiset työkonferenssit, joissa samanaikaisesti voi työskennellä lähes sata osallistujaa. Työkonferenssi on vuoropuheluun perustuva työyhteisöjen kehittämismetodi (ks. Lehtonen 2004). Työkonferensseja on monia erilaisia (ks. Vartiainen \& Pulkkis 2004). Mainitsen tässä vain omasta mielestäni mielenkiintoisimmat: tavistockilaiset 1950-luvulta kehittyneet Working-konferenssin, Searchkonferenssin ja Listering-Postin; pohjoismaisen 1980-luvulta kehittyneen Dialogikonferenssin sekä Suomessa 1990-luvulla kehitetyn Ennakointidialogin (ks. Arnkill, Erikson, Arnkill 2000). Mielenkiintoinen interventiometodi on myös kehittävän työntutkimuksen Muutoslaboratorio sekä ryhmä- ja yhteisödynamiikan tutkimiseen luotu Tavistock/Leicester Group Relation ${ }^{4}$ konferenssi (ks. Miller 1989). Ne kaikki rakentuvat dialogiselle työskentelyotteelle.

Ilmaisut coachaaja, fasilitaattori, auditoija, mentori, sparraaja, prosessikonsultti tai työnohjaaja kertovat metodista, jota konsultoinnissa sovelletaan. Konsultointi ei kuitenkaan ole metodia vaan suhde, jossa erilaisia työskentelyotteita sovelletaan sovitun tehtävän ja tavoitteen saavuttamiseksi. Metodi on väline. Interventio on sanan mukaisesti väliintuloa. Konsultoinnissa väliintulon tavoitteena on luoda jotakin parempaa kuin aikaisempi. Se palvelee kehittymistä ja uudistumista.

Työskentelyotteita valittaessa konsultin täytyy selvittää - dialogissa eli yhdessä asiakkaan kanssa mikä konsultointiprojektissa on kehittämisen kohteena. Kohteena voi olla uudelleenorganisointi, strategian jalkauttaminen, prosessijohtaminen, jonkun työyhteisön ryhmän toiminnan kehittäminen tai arviointi. Kohteena voi myös olla organisaation jäsenen tai ryhmän kehittyminen omassa työssään. Olennaista on, että kohteen määrittelyn jälkeen valitaan konsultointimetodi. Kukaan ei voi hallita kaikkea ja siksi myös konsultin täytyy erikoistua ja rajata osaamistaan. Ammattitaitoinen konsultti tietää mitä hän osaa ja mitä hän ei osaa, mutta hän ei koskaan ole vain yhden työskentelyotteen varassa.

Tutkivan konsultoinnin keskeisin metodi on tutkiva työote (Dewey 1933, Bion 1961). Sen avul- 
la on mahdollista oppia kokemuksesta ja se tähtää asiakkaan oman kehittämiskyvyn kehittämiseen. Tutkivan työotteen rakenneosat ovat dialogi, reflektio ja tulkinta (ks. Vartiainen 2003:91). Tutkiva työote on dialogisen työskentelyn perusväline: yhdessä ymmärtämisen työkalu.

\section{LOPUKSI}

Olen tässä artikkelissa tarkastellut dialogisuutta tutkivassa konsultoinnissa. Ymmärrän ja määrittelen dialogisuuden fenomenologisen filosofian traditiosta ja psykodynaamisesta ajattelusta käsin. Konsultointisuhde ymmärretään pohjautuvan yhteistoiminnalle ja halulle kehittyä. Asiakas on joutunut tilanteeseen, joka erinäisistä syistä on ei toivottu, mahdollisesti ahdistava ja jota hän haluaa muuttaa. Dialogisessa suhteessa konsultin tehtävänä on ymmärtää niitä syitä ja tekijöitä sekä sitä prosessia, joka on johtanut asiakkaan vääristyneeseen ja epäautenttiseen tilanteeseen. Konsultti siis aluksi kuuntelee vuorovaikutuksessa asiakkaansa ns. arkipuhetta (Heidegger 2000), joka näennäisesti paljastaa mutta itse asiassa verhoaa todellisuutta ja irrottaa asiakkaan tietoisuuden sen juurilta ja näin etäännyttää hänet ongelman todellisten syiden tunnistamisesta. Konsultointiprosessissa dialogin kautta asiakas tai asiakasorganisaatio voi kuitenkin tavoittaa ongelman syyt ja ymmärtää mistä on kysymys. Vaikka oivaltaminen on merkittävää ymmärtämisessä, ymmärtämisprosessi edellyttää sanoittamista. Emme voi ymmärtää emmekä nähdä omien väärinymmärrystemme läpi ja korjata niitä paitsi oman ymmärryksemme puitteissa. Käsittämättömästä tulee käsitettävää vasta kun se saa merkityksen. Juuri ymmärtäminen tuo uuden näkökulman, josta käsin asiakas tai asiakasorganisaatio voi lähteä muuttamaan toimintaansa ja uudistumaan. Ymmärtäminen on prosessi, joka ohjaa konsultointiprojektia. Dialogiset konsultoinnin metodit tukevat ja antavat paikan ja tilan tälle prosessille.

Yhteistoiminta - tasaveroisten, mutta erilaisten ja eri asemassa olevien toimijoiden välillä voi toteutua vain dialogissa. Se edellyttää keskinäistä kunnioitusta, luottamusta ja yhteisymmärrystä työskentelyn tavoitteista. Dialogi on väline yhteisymmärryksen rakentamisessa sovitusta tehtävästä ja toteutuksen muodoista. Työskentelytapana se antaa suojaa manipuloinnilta ja ryhmäimulta (ks. Bion 1961). Dialogissa sovittua tehtävää ei tarkastella vain yhdestä näkökulmasta eikä yhdestä toimijasta käsin. Päätös, toteutus ja toiminta ovat yhteisen ajattelun ja erilaisten näkökulmien yhdistämisen lopputulos.

\section{LÄHTEET}

Arendt, H. (2002). Vita Activa. Ihmisenä olemisen ehdot. Suom. Riitta Oittinen. Vastapaino. [Human Condition 1958]

Arnkill, T.E., Erikson, E. \& Arnkill, R. (2000). Kunnallisten palveluiden dialoginen kehittäminen. Ylisektorinen lastensuojelu, vanhustenhuolto ja kaupunkipolitiikka. Palmuke-raportti. Kansallisen työelämän kehittämisohjelma. Työpapereita 11.

Bion, W. (1961). Experiences in groups and other papers. Suom. Kokemuksia ryhmistä. London and New York: Routledge.

Bion, W. (1967). Second Thoughts. IV painos. London: Karnac.

Bohm, D. (1996). On Dialogue. London-New York: Routledge.

Buber, M. (1993).Minä ja Sinä. Suom. Jukka Pietilä, WSOY. [Ich und Du 1923]

Damasio, A. (1994). Descartes Error. Emotion, Reason and Human Brain. Suom. Kimmo Pietiläinen 2001. Terra Cognita.

Dewey, J. (1933). How we think. A restatement of the relation of reflective thinking to the educative process. New York: D.C. Heath and Company.

Gadamer, H-G. (2004). Hermeneutiikka. Ymmärtäminen tieteissä ja filosofiassa. Valikoinut ja suomentanut Ismo Nikander. Vastapaino.

Hankamäki, J. (2003). Dialoginen filosofia. Teoria, metodi ja politiikka. Yliopistopaino.

Heidegger, M. (2000). Oleminen ja aika. Suom. Reijo Kupiainen, Vastapaino. [Sein und Zeit, 1927].

Kolb, D. \& Frohmanin, A. (1970). An organizational development to consulting. Sloan $\mathrm{Ma}-$ nagement Reviews,. 12, 51-65.

Lehtonen, J. (toim.) (2004). Työkonferenssi Suomessa. Vuoropuheluun perustuva työyhteisöjen kehittämismetodi. Työturvallisuuskeskus.

Lehtovaara, J. (1996). Dialogisuus, reflektointi ja ihmisen maailmassa oleminen. Julkaisussa Lehtovaara, J. \& Jaatinen, R. (toim.) Dialo- 
gissa osa 1. Matkalla mahdollisuuteen.

Tampereen yliopisto. A21/1994. 2. painos, 213-233.

Levinas, E. (1996). Etiikka ja äärettömyys. Keskusteluja Philippe Nemon kanssa. Suom. Jari Setälä. Gaudeamus. [Ethique et infini, 1982, La trace de l'autre, 1982].

Miller, E. \& Rice, A. (1967). Systems of Organization: Task and Sentient systems and their Boundary Control. Tavistock. Social Science Paperback Edition. 1970, 1973, sekä Colman, A, \& Bexton (toim.) 1975 An A. K. Rice Institute Series. Selections in Group Relation Reader .(43-68.)

MILLER, R. (1989). The "Leicester Modell” : Experiential Study of Group and Organisational Processes. Occasional Paper No.10. London: Tavistock Institute of Human Relations.

Neumann, J. (1996). Negotiating entry and contracting. Teoksessa Neuman, J., Kelnner, K. \& Dawson-Shepherd A. (toim.), Developing Organizational Consultancy. A. London and New York: Routledge. (7-31).

Puro, U. \& Matikainen, J. (2000). Dialogi - yhdessä ajattelemisen taito. TSL.

RAUHALA, L. (1983). Ihmiskäsitys ihmistyössä. Gummerus.

Rauhala, L. (1989). Ihmisen ykseys ja moninaisuus.Gummerus.

Tähkä, V. (1997). Mielen rakentuminen ja psykoanalyyttinen hoitaminen. WSOY.

Vartiainen, E. (1999). Tunteiden ja vallan ryhmädynamiikka. Teoksessa Sari Näre (toim.) Tunteiden sosiologiaa II. Historiaa ja säätelyä. SKS. (270-295)
Vartiainen, E. (2003). Mistä konsultoinnissa on kysymys. Näkymiä tutkivaan konsultointiin. Työelämän tutkimus, 2, 86-94.

Vartiainen, E \& Pulkkis, A. (2004). Työkonferenssi työelämän kehittämisessä. Historiallisteoreettinen katsaus. Teoksessa Lehtonen, J. (toim.) Mikä ihmeen työkonferenssi. Työsuojelurahasto. (57-73)

Varto, J. (1996). Filosofinen ihmiskäsitys ja toiseus. Julkaisussa Lehtovaara, J. \& Jaatinen, R. (toim.) Dialogissa osa 1. Matkalla mahdollisuuteen. Tampereen yliopisto. A21/1994 2. painos. (83-113)

Winnicott, D.W. (1971). Playing and Reality. London: Tavistock Publication Limited.

Wittgenstein, L. (1999). Filosofisia tutkimuksia. Suom. Heikki Nyman. WSOY. [ Alkuteos Philosophische Unterschungen, 1953]

\section{VIIITTEET}

1. Myös Hans-Georg Gadamer kiinnittää huomion väliin jäävään tilaan (in diesem Zwischen) teoksessaan Totuus ja mentelmä (1960: 295, 279).

2. Ks. lisää artikkelista Vartiainen (1999). Tunteiden ja vallan ryhmädynamiikka.

3. Sovellan Kolbin ja Frohmanin (1970) ja Jean Neumannin (1997, 9-31) edelleen kehittämää konsultointiprosessin viitekehystä "The cycle of planned change”.

4. Suomessa Tavistock/Leicester konferenssia toteutetaan Tavistock Seminaari -nimellä. Niitä järjestää Organisaatiodynamiikka ry. yhdessä Metanoia Instituutin kanssa. 